\title{
Extraventricular Neurocytoma: Morphological and Immunohistochemical Considerations on Differential Diagnosis
}

\author{
Anna Maria Buccoliero ${ }^{1}$, Adele Caldarella ${ }^{1}$, Franco Ammannati ${ }^{2}$, \\ Pasquale Mennonna ${ }^{2}$, Antonio Taddei ${ }^{3}$, Gian Luigi Taddei ${ }^{1}$ \\ ${ }^{1}$ Dipartimento di Patologia Umana e Oncologia, Università degli Studi di Frenze, Frenze, \\ ${ }^{2}$ Unità operativa di Neurochirurgia, Policlinico di Careggi, Frenze, \\ ${ }^{3}$ Dipartimento di Area Critica Medico-Chirurgica Sezione Chirurgia Generale e D.C.,
} Frenze

\section{Summary}

Neurocytoma is an unusual neuronal tumor especially affecting young people. It commonly arises in the ventricles and has a benign outcome. Herein, we report on a rare case of extraventricular neurocytomas (right parietal lobe) in a young girl admitted to hospital for a cranial trauma subsequent to a seizure. The tumor, radiologically well-circumscribed, cystic and enhancing, was surgically excised. The patient, who received no post surgical treatment, is alive and well after 18 months of follow-up. Pathological examination showed a well-differentiated lesion composed of uniform, round cells with perinuclear halos in a neuropil background and immunohistochemically positive for neuronal markers (synaptophysin, neuron-specific enolase, neurofilaments). The authors emphasize the role of the morphological and immunohistochemical evaluations to recognize this rare tumor.

Key words: Neurocytoma - Extraventricular - Clear cells - Brain tumors - Synaptophysin

\section{Introduction}

Central nervous system neurocytomas are infrequent tumors that occur supratentorially in the lateral ventricles near the foramina of Monro or in the septum pellucidum
$[3,10,11,18,19]$. Neurocytomas without any connection to the ventricular system have also been described $[2,3,4,7,8,13,14,27,31,34,39,43,44]$. In the literature, about 200 cases of central neurocytoma [47] and about 60 cases of extraventricular neurocytoma are reported $[2,3,4,7,8,13,14,27,31,34,39,43,44]$; their incidence has been calculated to range between 0.25 and $0.5 \%$ of all intracranial tumors [47].

In the last few years, owing to the common clear cell feature, these tumors were frequently misdiagnosed as clear cell ependymomas or intraventricular oligodendrogliomas [47]. In 1982, Hassoun was the first to use the term "central neurocytoma" [17]. At the present time, the definition of "central neurocytoma" is restricted to neoplasms located within the ventricles, whereas the terms "extraventricular neurocytoma" and "cerebral neurocytoma" are used for central neurocytoma-like tumors at the morphological, immunohistochemical, and prognostic levels, but arising at other sites, i.e. spinal cord, cerebellum, and different lobes of cerebral hemispheres [47].

Neurocytomas, either at ventricular or extraventricular location, commonly affect young adults and have a

Address for correspondence: Gian Luigi Taddei, Dipartimento di Patologia Umana e Oncologia, Università degli Studi di Firenze, viale G.B. Morgagni, 85, 50134 Firenze, Italy. Tel.: +39-55/413756 Fax: +39-55/4379868.

E-mail: gl.taddei@unifi.it 
benign clinical course [47]; nevertheless, age at clinical presentation may range from a few days to over 65 years, and in rare cases, an unfavorable outcome was reported $[3,9,10,24,28,32,37,41,47,48]$.

We report on a case of extraventricular neurocytoma arising in the right parietal lobe of a young girl. Furthermore, comparing the morphological and immunohistochemical aspects of neurocytoma with those of some extraventricular and intra-axial primary clear cell tumors, we searched for simple, rapid, and decisive elements for the differential diagnosis on routinely formalin-fixed, paraffin-embedded specimens.

\section{Clinical History}

The patient, a 20 year old woman, was admitted to the Neurosurgical Service (Careggi Hospital, Florence, Italy) for a cranial trauma subsequent to a seizure.

Computed tomography (CT) showed a parietal mass of $2.5 \mathrm{~cm}$ in the right hemisphere. The lesion was located at the cortical/sub cortical zone and appeared wellcircumscribed and cystic, with a small peripheral solid part. Only scant edema was appreciable at the peritrigonal white matter level. Homogeneous contrast enhancement of the solid component was detectable following administration of contrast medium. Magnetic resonance confirmed the presence of a cystic and enhancing tumor (Fig. 1).

The tumor was surgically excised. A gray-green liquid was aspirated from the cystic area. The neoplastic tissue was brown and bleeding, without macroscopically evident precise demarcation from the non pathological brain parenchyma.

The postoperative course was uncomplicated. The patient received no postoperative treatment, and is alive and well with no lesion persistence or recurrence 18 months after surgery.

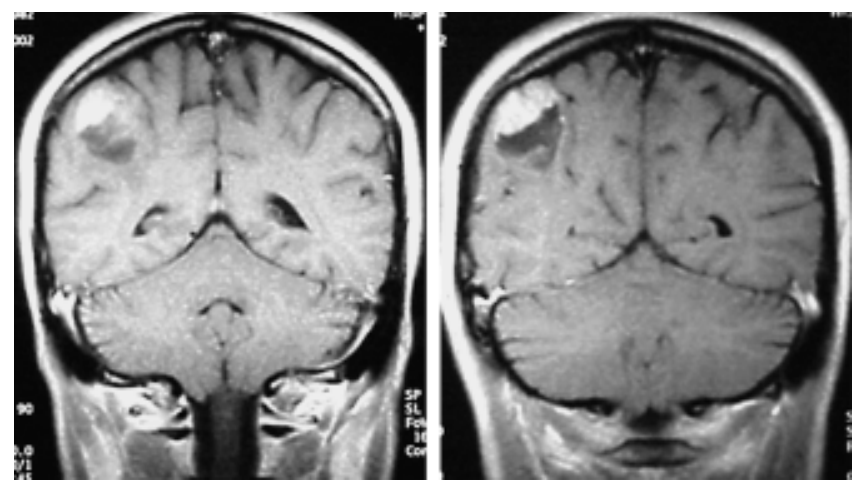

Fig. 1. Sagittal MRI . The lesion was located in the right parietal lobe at the cortical/subcortical level and appeared cystic and contrast-enhancing with a small peripheral solid part.

\section{Materials and Methods}

The surgical specimen available for the histopathological evaluation was fixed in $10 \%$ buffered neutral formalin, entirely sampled, and embedded in paraffin. Some sections were stained with hematoxylin-eosin (HE) for the morphological evaluation, whereas other sections were mounted on electrostatic slides and used for immunohistochemical study. The primary used antibodies were as follows: monoclonal antibody against synaptophysin (SY), neuron-specific enolase (NSE), glial fibrillary acidic protein (GFAP), and Ki-67 (Mib-1); multiclonal antibody against neurofilaments (NF); polyclonal antibody and S-100 protein (for clone, dilutions, and sources of antibodies, see Table 1). The sections used for immunohistochemistry were air-dried overnight at $37{ }^{\circ} \mathrm{C}$, deparaffinized through xylene, and dehydrated through graded alcohol. Endogenous peroxidase activity was blocked by immersing the specimens in a solution of $0.5 \% \mathrm{H}_{2} \mathrm{O}_{2}$. To recover antigenicity, the slides were placed in a citrate buffer $(10 \mathrm{mM}, \mathrm{pH} 6.0)$ and submitted to microwave antigen enhancement $(300 \mathrm{~W}$ for $40 \mathrm{~min}$ ). The sections were allowed to cool down to room temperature, washed with phosphate-buffered saline solution (PBS, $\mathrm{pH} 7,4$ ), and treated with normal horse serum (LAB VISION Corporation, Fremont, California) to reduce non-specific antibody binding. After washing in PBS, the sections were incubated with biotinylated anti mouse IgG (LAB VISION) and then with streptavidin-biotin-peroxidase complex reagent (LAB VISION). Following extensive washing with PBS, the slides were treated with 3,3'-diaminobenzidine-hydrogen peroxide (BioGenex, San Ramon, California) as a final indicator, and lightly counterstained with Mayer's hematoxylin. Negative control experiments were conducted by replacing the primary antibodies with non-immune mouse serum at an equivalent protein concentration. An additional section was stained with periodic acid Shiff (PAS).

\section{Results}

Light microscopy revealed a monotonous pattern of round cells with large, clear cytoplasm, and round nucleus with an appreciable "salt and pepper" chromatin. Cellularity was moderate in a neuropil-like background (Fig. 2). Acellular PAS-positive areas without neuropillike matrix were also recognizable (Fig. 3). The lesion did not show necrosis, and the mitoses were exceptional. Vascularization was rich with frequent hyalinization of the blood vessels. Occasionally, micro-hemorrhagic areas or psammomatous bodies were observed. Non neoplastic reactive astrocytes were present. Homer Wright rosettes and areas of ganglionic differentiation were absent.

Immunohistochemical studies led to diffuse and intense staining for SY, NF, and NSE in the cytoplasm and neuropil, disclosing the neuronal nature of the lesion (Fig. 4; Tab. 1); S-100 protein was also positive, whereas GFAP stained the reactive astrocytes (Fig. 4; Tab. 1). The proliferation marker Mib-1 gave evidence of a very low growth fraction $(<2 \%)$ (Tab. 1). 
Fig. 2. Light microscopy revealed a monotonous pattern of round cells with large, clear cytoplasm and round nucleus (A-C). There was moderate cellularity in a neuropillike background (D).
Fig. 3. Acellular PAS positive areas without a neuropil-like matrix were also recognizable.
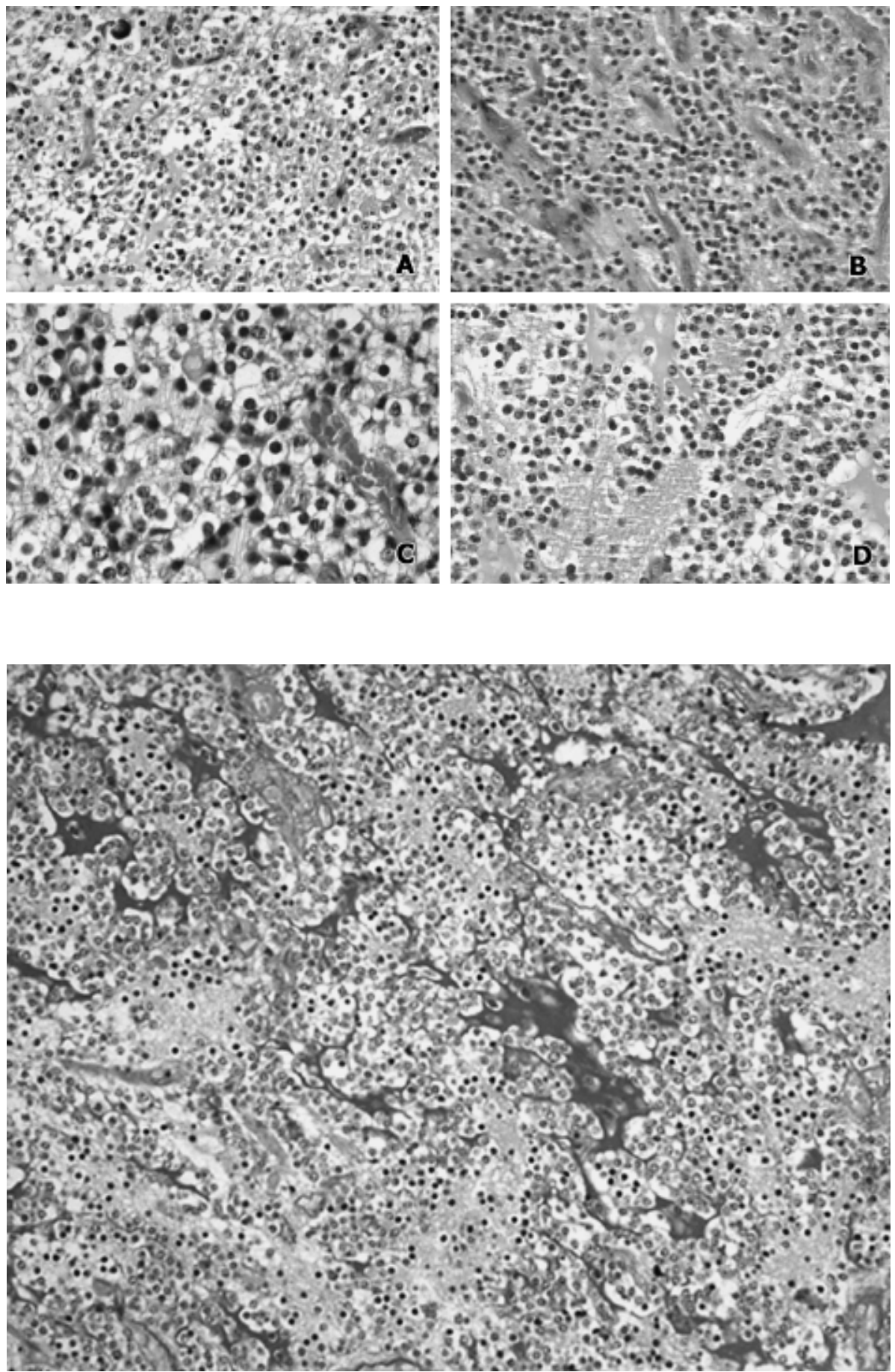

\section{Discussion}

Neurocytoma is a rare neoplasm that commonly occurs at juvenile age [47]. Radiologically, neurocytoma appears as a well circumscribed, rounded or multilobated and enhancing lesion [47]. It often shows cystic areas or calcifications [47].
At the light microscopic level, central nervous system neurocytoma is composed of a monomorphic population of round cells with uniform nuclear size and shape and "salt and pepper" chromatin [3, 47]. A neuropil-like background and zones of acellular fibrillary matrix are typical $[3,5,11,14,19,27,36,47]$. Neurocytoma, particularly at extraventricular location, may 

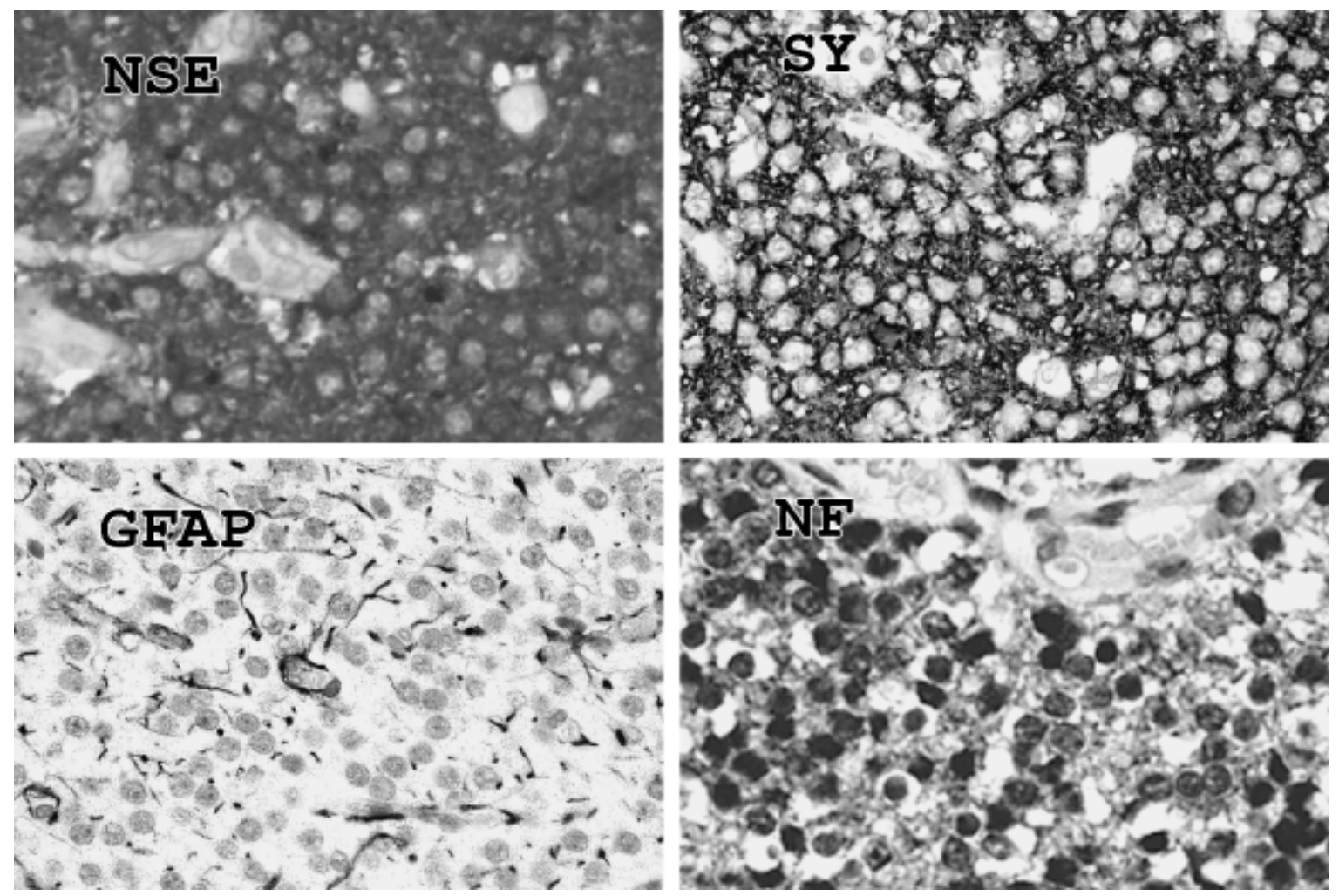

Fig. 4. Immunohistochemical studies displayed diffuse and intense SY, NF, and NSE staining; GFAP-positive reactive astrocytes are present.

Table 1. Clone, dilution, and source of antibodies used and immunohistochemical results

\begin{tabular}{lllll}
\hline Antibody & Clone & Dilution & Source & Results (Clear cells) \\
\hline SY & Snp 88 & Prediluted & $\begin{array}{l}\text { BioGenex } \\
\text { (San Ramon, California) }\end{array}$ & + \\
NF & DA2; FNP7; RMb020.11 & $1: 20$ & $\begin{array}{l}\text { Zymed Laboratories } \\
\text { (San Francisco, California) }\end{array}$ & + \\
NSE & MIG-N3 & Prediluted & $\begin{array}{l}\text { BioGenex } \\
\text { (San Ramon, California) }\end{array}$ & + \\
S-100 & - & $1: 2000$ & $\begin{array}{l}\text { Dako } \\
\text { (Glostrup, Denmark) }\end{array}$ & + \\
GFAP & ZCG29 & Prediluted & $\begin{array}{l}\text { Zymed Laboratories } \\
\text { (San Francisco, California) }\end{array}$ & - \\
Mib-1 & Mib-1 & IMMUNOTECH \\
\end{tabular}

also show ganglionic differentiation $[13,33]$. For these cases, the definition of "ganglioneurocytoma" was introduced [13, 33]. Most intriguing is the oligodendroglioma-like appearance with a honeycomb feature; this appearance may cause difficulty in the diagnosis, particularly at less common extraventricular sites. Tumoral cells with regular round nucleus and clear cytoplasm resembling oligodendrocytes are detectable in oligodendrogliomas as well as in a great number of central nervous system and intracranial neoplasms, i.e. 
neurocytoma, clear cell ependymoma, liponeurocytoma, dysembryoblastic neuroepithelial tumor (DNT), pilocytic astrocytoma, pineocytoma, clear cell meningioma, hemangioblastoma, pituitary adenoma, germinoma, medulloblastoma (particularly in its variant, called cerebellar neuroblastoma) and metastasis $[6,15$, $22,42]$. Moreover, papillary glioneuronal tumor, a distinct recently reported lesion composed of neurocytes, ganglio and glial cells and with a pseudopapillary architecture, may resemble an oligodendroglioma [25]. Non-tumoral lesions, i.e. demyelinating disorders, and xanthomatous change sometimes also assume a clear cell-like appearance [15]. The clear perinuclear halo, generally absent in frozen sections, rapidly fixed tissue, and paraffin sections obtained from frozen material [47], is commonly considered an artifact related to delayed fixation when the cytoplasm is particularly rich in "mucoid", i.e. glycosamminoglycans or lipidic material [38]. In electron microscopic studies of clear cell ependymomas, it was demonstrated that the peripheral parts of the cytoplasm of the tumoral clear cells were devoid of cellular organelles showing intracellular edema, and vacuolization underlining the compartmentation of the organelles was an important cause of tumoral perinuclear halo [30].

The interpretation of the clear cell lesions may be difficult, and misdiagnosis and subsequent mistreatments are possible.

Excluding the tumors with a specific and typical location or those in which clear cell areas are often focal, i.e pilocytic astrocytoma, liponeurocytoma, cerebral ganglioglioma, pituitary adenoma, germinoma, pineocytoma, and hemangioblastoma, and excluding the extra axial neoplasms, i.e. meningioma, the most exact differential diagnosis ranges between extraventricular neurocytoma and DNT, clear cell ependymoma, oligodendroglioma, and papillary glioneuronal tumor.

Certainly, the ultrastructural study may be helpful as far as the characterization of the histogenetic lineage and grade of maturation of neoplasias with similar histology are concerned. As early as 1982, Hausson [17] used electron microscopy to identify neuronal differentiation (microtubules, neurosecretory granules, synapses) in neurocytoma, and more recently, Cenacchi [6] underlined the utility of electron microscopy in defining the lesions composed of oligodendroglial-like cells. The contribution of the ultrastructural evaluation may be particularly helpful when only scant material is available, such as in the case of stereotaxic biopsy, or when the tissue has a prolonged fixation so that the immunohistochemical results may be altered [6].

Nevertheless, if precise clinical data and adequate tumoral samples are available, the correct diagnosis can also be rendered by morphological and immunohistochemical studies.
Long-standing, drug-resistant partial seizures in a young patient, temporal localization, the presence of mucin-rich "patterned" intracortical nodules with floating neurons, and the detection of cortical dysplasia suggest DNT [12, 16, 21, 26].

A large hemispheric enhancing cystic lesion arising in a child, well demarcated by the adjacent brain and with perivascular and/or true ependymal rosettes (Homer Wright rosette are sometimes detectable in neurocytoma [27]) suggest clear cell ependymoma [1, 20, $22,23,30,35]$.

However, the tumor most commonly considered in the differential diagnosis of neurocytoma is oligodendroglioma. It generally affects the frontal lobe of older patients (young-to middle-aged adults). Although some authors believe that oligodendroglioma and neurocytoma are morphologically identical, some important differences should be considered [27, 34, 35, 46]:

- A delicate vascular pattern with a "chicken wire" aspect, and the presence of minigemistocytes are common in oligodendroglioma.

- A prominent fibrillary background is more typical of neurocytoma.

- In the region of cortical invasion, perineuronal satellitosis is more characteristic of oligodendroglioma.

Regarding papillary glioneuronal tumor, the clinical and radiological findings are similar to cerebral neurocytoma, but the characteristic pseudopapillary architecture (hyalinized blood vessels surrounded by regular cells) helps in rendering the correct diagnosis [25] .

Basic data are available from the immunohistochemical characterization of the clear cells. A distinctive feature of neurocytoma is the positivity of the oligodendroglial-like cells for neuronal markers $[3,5,7,10,11$, $14,19,27,29,36,40,45,46]$. This case showed clear immunopositivity for SY, NSE, and NF. In particular, synaptophysin, a $38 \mathrm{Kd}$ protein associated with the synaptic vescicle membrane $[14,29,40]$, is considered the most useful marker in view of its specificity to the identification of neuronal differentiation in brain tumors. In contrast to oligodendroglioma, the most difficult lesion to be distinguished from neurocytoma, and in contrast to clear cell ependymoma and DNT, diffuse and intense synaptophysin immunoreactivity is very common in neurocytoma $[3,5,7,10,11,14,19,21,23,27$, $29,30,36,40,45]$. Papillary glioneurocytoma may also be synaptophysin-positive; nevertheless, GFAP expression in the cells covering the vessels in the pseudopapillary structures is typical [25].

In conclusion, we believe that if precise clinical data are available, morphological and immunohistochemical studies suffice to distinguish neurocytoma from more aggressive lesions, such as ependymoma or oligodendroglioma, and from papillary glioneuronal tumor and DNT (a quasi-hamartomatous glioneural process). 


\section{References}

1. Akutsu H, Shibata Y, Okazaki M, Hyodo A, Matsumura A (2000) Intramedullary clear cell ependymoma in the cervical spinal cord: case report. Neurosurgery 47: 1434-1437

2. Biernat W, Zakrzewski K, Liberski PP (2000) January 2000: 12 year old boy with recent onset seizures. Brain Pathol 10: 313-314

3. Brat DJ, Scheithauer BW, Eberhart CG, Burger PC (2001) Extraventricular neurocytomas. Pathologic features and clinical outcome. Am J Surg Pathol 25: 1252-1260

4. Brown DM, Karlovitis S, Lee LH, Kim K, Rothfus WE, Brown HG (2001) Management of neurocytomas: case report and review of the literature. Am J Clin Oncol 24: 272-278

5. Casadei GP, Arrigoni GL, Versari P, Gambacorta M, Giangaspero F (1991) Central neurocytoma. A clinico-pathologic study of five cases. Tumori 77: 323-327

6. Cenacchi G, Giangaspero F, Cerasoli S, Manetto V, Martinelli GN (1996) Ultrastructural characterization of oligodendroglial-like cells in central nervous system tumors. Ultrastruct Pathol 20: 537-547

7. Coca S, Moreno M, Martos JA, Rodriguez J, Barcena A, Vaquero J (1994) Neurocytoma of spinal cord. Acta neuropathol (Berl) 87: 537-540

8. Enam SA, Rosenblum ML, Ho KL (1997) Neurocytoma in the cerebellum. Case report. J Neurosurg 87: 100-102

9. Eng DY, De Monte F, Ginsberg L, Fuller GN, Jaeckle K (1997) Craniospinal dissemination of central neurocytoma. J Neurosurg 86: 547-552

10. Favereaux A, Vital A, Loiseau H, Dousset V, Caille J, Petry K (2000) Histopathological variants of central neurocytoma: report of 10 cases. Ann Pathol 20: 558-563

11. Figarella-Branger D, Pellissier JF, Daumas-Duport C, Delisle MB, Pasquier B, Parent M, Gambarelli D, Rougon G, Hassoun J (1992) Central Neurocytomas. Critical evaluation of a small-cell neuronal tumor. Am J Surg Pathol 16: 97-109

12. Fujimoto K, Ohnishi H, Tsujimoto M, Hoshida T, Nakazato Y (2000) Dysembryoplastic neuroepithelial tumor of the cerebellum and brain stem. J Neurosurg 93: 487-489

13. Funato H, Inoshita N, Okeda R, Yamamoto S, Aoyagi M (1997) Cystic ganglioneurocytoma outside the ventricular region. Acta Neuropathol (Berl) 94: 95-98

14. Giangaspero F, Cenacchi G, Losi L, Cerasoli S, Bisceglia M, Burger PC (1997) Extraventricular neoplasms with neurocytoma features. A clinicopathological study of 11 cases. Am J Surg Pathol 21: 206-212

15. Gökden M, Roth KA, Carrol SL, Wick MR, Schmidt RE (1997) Clear cell neoplasms and pseudoneoplastic lesions of the central nervous system. Semin Diagn Pathol 14: 253-269

16. Gyure KA, Sandberg GD, Prayson rA, Morrison AL, Armostrong RC, Wong K (2000) Dysembryoplastic neuroepithelial tumor. An immunohistochemical study with myelin oligodendrocyte glycoprotein. Arch Pathol Lab Med 124: 123-126

17. Hassoun J, Gambarelli D, Grisoli F, Pellet W, Salomon G, Pellisier JF, Toga M (1982) Central neurocytoma. An electron-microscopic study of two cases. Acta Neuropathol 56: $151-156$
18. Hassoun J, Söylemezoglu F, Gambarelli D, Figarellabranger D, Ammon K, Kleihaus P (1993) Central neurocytoma: a synopsis of clinical and histological features. Brain Pathol 3: 297-30

19. Hessler RB, Lopes MBS, Frankfurter A, Reidy J, VandenBerg SR (1992) Cytoskeletal immunohistochemistry of central neurocytomas. Am J Surg Pathol 16: 1031-1038

20. Hirato J, Nakazato Y, Iijima M, Yokoo H, Sasaki A, Yokota M, Ono N, Hirato M, Inoue H (1997) An unusual variant of ependymoma with extensive tumor cell vacuolzation. Acta Neuropahol (Berl) 93: 310-316

21. Honavar M, Janota I, Polkey CE (1999) Histological heterogeneity of dysembryoplastic neuroepithelial tumor: identification and differential diagnosis in a series of 74 cases. Histopathol 34: 342-356

22. Kakita A, Takahashi H, Fusejima T, Konno K, Nakazawa T, Aoki Ktanaka R, Ikuta F (1995) Clear cell cariants of intracranial tumors: meningioma and ependymoma. Noshuyo Byori 12: 111-116

23. Kawano N, Yada K, Yagishita S (1989) Clear cell ependimoma. A histological variant with diagnostic implications. Virchows Arch A Pathol Anat Histopathol 415: 467-472

24. Kim DG, Kim JS, Chi JG, Park SH, Jung HW, Choi KS, Han DH (1996) Central neurocytoma: proliferation potential and biological behaviour. J Neurosurg 84: 742-747

25. Komori T, Scheithauer BW, Anthony DC, Rosenblum MK, McLendon RE, Scott M, Okazaki H, Kobayashi M (1998) Papillary glioneuronal tumor. A new variant of mixed neuronal-glial neoplasm. Am J Surg Pathol 22: $1171-1183$

26. Leung SY, Gwi E, Ng HK, Fung CF, Yam KY (1994) Dysembryolastic neuroepithelial tumor. A tumor with small neuronal cells resembling oligodendroglioma. Am J Surg Pathol 18: 604-614

27. Louis DN, Swearingen B, Linggood RM, Dickersin GR, Kretschmar C, Bhan AK, Hedley-Whyte T (1990) Central nervous system neurocytoma and neuroblastoma on adults-report of eight cases. J Neurooncol 9: 231-238

28. Mackenzie IRA (1999) Central Neurocytoma. Histologic atypia, proliferation potential, and clinical outcome. Cancer 85: 1606-1609

29. Miller DC, Koslow M, Budzilovich GN, Burstein DE (1990) Synaptophysin: a sensitive and specific marker for ganglion cells in central nervous system neoplasms. Hum Pathol 21: 271-276

30. Min KW, Scheithauer BW (1997) Clear cell ependymoma: a mimic of oligodendroglioma: clinicopathologic and ultrastructural considerations. Am J Surg Pathol 21: 820-826

31. Möller-Hartaman W, Krings T, Brunn A, Thron A (2002) Proton magnetic resonance spectroscopy of neurocytoma outside the ventricular region-case report and review of the literature. Neuroradiology 44: 230-234

32. Mrak RE (1994) Malignant neurocytic tumour. Hum Pathol 25: 747-752

33. Nishio S, Takeshita I, Fukui M (1990) Primary cerebral ganglioneurocytoma in an adult. Cancer 66: 358-362

34. Nishio S, Tashima T, Takeshima I, Fukui M (1988) Intraventricular neurocytoma: clinicopathological features of six cases. J Neurosurg 68: 665-670 
35. Perry A (2001) Oligodendroglial neoplasms: Current concepts, misconceptions, and folklore. Adv Anat Pathol 8: 183-199

36. Robbins P, Segal A, Narula S, Stokes B, Lee M, Thomas W, Caterina P, Sinclair I, Spagnolo D (1995) Central neurocytoma. A clinicopathological, immunohistochemical and ultrastructural study of 7 cases. Pathol Res Pract 191: $100-111$

37. Sgouros S, Carey M, Aluwihare N, Barber P, Jackowski A (1998) Central neurocytoma : a correlative clinicopathologic and radiologic analysis. Surg Neurol 49: 197-204

38. Schiffer D (1996) Brain Tumors. Biology, pathology, and clinical references. Springer-Verlag, Berlin Heidelberg New York

39. Shunji N, Takesita I, Kaneo Y, Fukui M (1991) Cerebral neurocytoma. A new subset of benign neuronals tumors of the cerebrum. Cancer 70: 529-537

40. Smith TW, Nikulasson S, De Girolami U, De Gennaro LJ (1993) immunohistochemistry of synapsin I and synaptophysin in human nervous system and neuroendocrine tumors. Applications in diagnostic neuro-oncology. Clin Neuropathol 12: 335-342

41. Soylemezoglu F, Scheithauer BW, Esteve J, Kleihues P (1997) Atypical central neurocytoma. J Neuropathol Exp Neurol 56: 551-556

42. Taddei GL, Buccoliero AM, Caldarella A, Conti R, Di Lorenzo N, Cacciola F, Franchi A (2001) Cerebellar lipo- neurocytoma: immunohistochemical and ultrastructural study of a case. Ultrastrastruct Pathol 25: 59-63

43. Tortori-Donati P, Fondelli MP Rossi A, Cama A, Brisigotti M, Pellicanò G (1999) Extraventricular neurocytoma with ganglionic differentiation associated with complex partial seizures. Am J Neuroradiol 20: 724-727

44. Vallat-Decouvelaere AV, Gauchez P, Varlet P, Delisle MB, Popovic M, Boissonnet H, Gigaud M, Mikol J, Hassoun J (2000) So-called malignant and extra-ventricular neurocytomas: reality or wrong diagnosis? A critical review about two overdiagnosed cases. J Neurooncol 48: 161-172

45. von Deimling A, Kleihues P, Saremaslani P, Yasargil M G, Spoerri O, Wiestler S, Wiestler OD (1991) Histogenesis and differentiation potential of central neurocytomas. Lab Invest 64: 585-591

46. Wilson A J, Leaffer DH, Kohout ND (1985) Differentiated cerebral neuroblastoma: a tumor in need of discovery. Hum Pathol 16: 647-649

47. World Health Organization Classification of Tumors (2000) Pathology and genetics of tumours of the nervous system, p 107 IARC Press Lyon

48. Yasargil MG, von Ammon K, von Deimling A, Valavanis A, Wichmann W, Wiestler OD (1992) Central neurocytoma: histopathological variants and therapeutic approaches. J Neurosurg 76: 32-37

Received: June 3, 2002

Accepted in revised version: August 27, 2002 